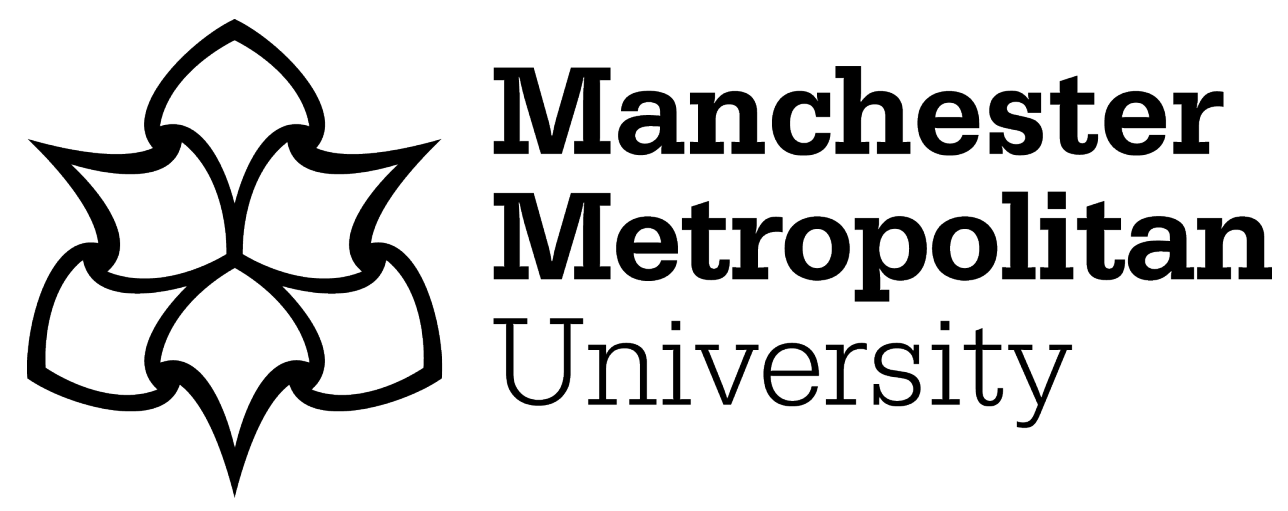

Burton, Mark and Kagan, Carolyn (2005) Liberation social psychology: learning from Latin America. Journal of community \& applied social psychology, 15 (1). pp. 63-78. ISSN 1052-9284

Downloaded from: https://e-space.mmu.ac.uk/14582/

Version: Accepted Version

Publisher: John Wiley \& Sons

DOI: https://doi.org/10.1002/casp.786

Please cite the published version 
Burton, M and Kagan, C (2005) Liberation Social Psychology: Learning

from Latin America Journal Community and Applied Social Psychology, 15, (1),

$63-78$

\title{
Liberation Social Psychology: Learning From
}

\section{Latin America ${ }^{1}$}

\author{
Mark Burton* \\ Manchester Learning Disability Partnership
}

Carolyn Kagan

Department of Psychology and Speech Pathology and Institute of Health and Social Change, Manchester Metropolitan University

1 Some of the material in this article was previously presented by MB at:- the Community and Critical Psychology conference - Birmingham Sept. 2003, the British Psychological Society - History and Philosophy section conference, March 2002 and the Community and Organisational Psychology Research group, Manchester Metropolitan University, January 2002.

This is part of a longer project with aims of understanding the development of Latin American Social Psychology of Liberation, and reviewing its potential contribution to theory and practice of applied psychology in the British (and related) context.

The article is based on a) reading the literature in Spanish (and where available) in English, but not the Brazilian literature in Portuguese; b) attendance at the International Congresses of Social Psychology for Liberation in 2001 and 2002; c) discussions with Latin American and other colleagues working within this framework; d) visits to Venezuelan community social psychology projects in 1996 and 2002, and e) the responses to an email questionnaire to selected leaders in the field in 2002.

We are grateful to Maritza Montero, Jorge Mario Flores, Bernardo Jiménez, Joel Vázquez, Ignacio Dobles, and others for encouragement, discussions, materials, advice on reading and feedback and to lan Parker for the loan of books. 
* Manchester Learning Disability Partnership, Mauldeth House, Mauldeth Road West, Manchester, M21 7RL email: mark.burton@poptel.org 


\section{Liberation Social Psychology: Learning From}

\section{Latin America}

\section{Abstract}

Liberation Social Psychology (la psicología social de la liberación, LSP) has developed amongst a body of psychologists in Latin America over the last decade. There has been no survey of the field in English, although some of the ideas are of relevance for those working with oppressed groups elsewhere in the world. This article explores the context in which LSP grew from the work of Ignacio Martín-Baró and was developed by Maritza Montero, amongst others. Within LSP, key concepts emerge, including 'conscientization', 'realismo-critico', 'de-ideologisation', a social orientation, 'the preferential option for the oppressed majorities' and methodological eclecticism. The application of LSP is explored with reference to three domains. First, it is suggested that community social psychology as practised in some parts of Latin America reflects LSP in its emphasis on social transformation and participatory methods. Second, psycho-social work with victims of state oppression, which adopts a highly social and societal orientation embodies LSP. Third, social analyses which explicitly adopt socio-psychologicalpolitical analyses of the social realities confronting countries in Latin America embrace, in different ways, principles and concepts of LSP. Some of the challenges facing LSP are discussed and open dialogue is encouraged between LSP and critical, community and applied social psychologists.

201 words 
Key Words:

Liberation Social Psychology; oppression; transformation 
Caminando, caminando

Voy buscando libertad

Ojalá encuentre camino

Para seguir caminando

Walking, walking on

I'm looking for freedom

Let's hope I find the path

To keep walking on

Victor Jara [d. September 1973] (1970)

Over the last decade a new field and movement of psychologists, Liberation Social Psychology² (psicología social de la liberación - LSP) has taken form in Latin America. It has earlier origins, but it is only fairly recently that psychologists have used this term to identify and orientate their work. The orientation is now beginning to receive interest in Europe (Blanco, 1998; Burton, in press; de la Corte Ibañez, 2001, undated) and North America (Aron \& Corne, 1996; Lykes, 2000; Watts \& Serrano-García, 2003). As yet,

${ }^{2}$ This title is a little problematic. The Spanish term is La Psicología Social de la Liberación. It could translate as Social Psychology of Liberation, Liberation Social Psychology, or Social Psychology for Liberation. Each of the terms has been suggested by someone working in this field with good knowledge of Spanish and English. 
however there has been no survey of the field in English (but see Dobles, 1994; Montero, 2000b for analyses of the field in Spanish).

As we shall see below, key locations and socio-political contexts for this work have included repression and civil war in El Salvador, the aftermath of the dictatorships in Chile, Argentina and other countries, the experience of poor, marginalised and/or migrant communities in Venezuela, Puerto Rico, Costa Rica, and Brazil. Other contributions have come from Mexico, Cuba and Colombia, and outside the region from Spain the USA and Canada. More recently, workers from South Africa and Australasia have identified with this body of theory and practice.

\section{Why consider Liberation Social Psychology?}

It is important to recognise that Liberation Social Psychology developed in a very different context to our own European one. The societies of Latin America are far from identical, but are all characterised to a greater or lesser extent by endemic poverty and exclusion often affecting the majority of the population. This is a result of both the dependent and neo-colonial nature of their economies and severe internal inequalities (Sánchez \& Wiesenfeld, 1991). Intellectuals are often less integrated into the state's systems than here and this has often allowed a certain freedom to develop autonomous approaches that don't serve the state or oligarchy (Jiménez 1990). Latin American intellectual traditions in psychology and social science, while influenced by those from the English speaking world (especially North America) also differ, with a greater influence of European continental 
traditions (especially phenomenology, psychoanalysis, critical theory and Marxism, and structuralism). However as de la Torre (1997) demonstrates, dependency has been a powerful theme in the psychology of the region.

Despite the differences between Latin America and Europe, there are a number of reasons for considering and learning from this Latin American body of work.

\section{As a response to criticisms of traditional psychology}

Much of the work that underpins LSP developed in response to the 'crisis of social psychology' of the 1970s. That crisis was experienced in Britain, and North America (Armistead, 1974; Parker, 1989), but also acutely in Latin America. It may be summarised in terms of three problems with empirical social psychology (de la Corte lbañez, undated): -

A Its social irrelevance - social psychology did not seem to be producing much practical knowledge that addressed the social problems either within the societies in which it was being developed or elsewhere.

B A parochial context of discovery combined with pretension of universal validity - social psychology was over dependent on investigations of particular populations in artificial settings (especially undergraduate students in formal experiments). Despite this it attempted to suggest general social psychological principles that would apply to all human beings in all contexts. 
$C$ The imitation of scientific neutrality meant a denial of the moral dimension - a supposed value freedom.

However, the route taken by LSP in responding to the challenges has differed from that in the 'core countries ${ }^{31}$, where the academic field has settled into a broadly peaceful co-existence between empiricists and social constructionists. Much of the critical effort in the core countries has remained within the academic community at a highly theoretical level, with little impact on psychological work in field contexts (Burton, 2004). In the LSP movement on the other hand, there has been a focus on developing a psychology that is theoretically and practically adequate to the profound social problems of Latin America.

\section{As model for working with oppressed groups}

LSP developed specifically in relation to the problem of the 'popular majorities', the oppressed, marginalised, excluded masses in Latin America. We too, in the 'developed' economies, have oppressed and marginalised populations in our midst, such as people marginalised because of the way our society discriminates on the basis of disability, age, ill health, nationality, appearance, gender, sexuality and poverty. Psychology as a whole has neglected this fact of exclusion, it hardly making an entry into the formal literature (Burton \& Kagan, in press). The special conditions in Latin America, particularly the experience of state and paramilitary terror in many of the

\footnotetext{
${ }^{3}$ This term refers to the countries chiefly in North America and Europe that are
} central to the dominant global economic system, and is used in contrast to those whose economies are peripheral. 
countries, also make LSP a valuable resource for our context, whether working with refugees fleeing persecution and torture, or trying to help rebuild fractured communities.

\section{In the global context}

Latin American psychologists working with a liberatory orientation tend to see themselves as part of a broader movement for social and economic justice. Key areas addressed in LSP include commitment, ideology, subjectivity and identity. These are fundamental to any collective action that mobilises people, and especially that which emphasises unity in diversity. The recent mass mobilisation of people against the US neo-conservatives' wars, and the ongoing struggle to protect public services, are two examples of resistance to the globalising neoliberal phase of capitalist expansion for which tools from LSP could be a helpful resource.

\section{Understanding its context}

LSP should be understood as part of a broader intellectual and political movement that began in Latin America in the 1960s, and continues with renewed vigour now. All of its currents have been concerned with rethinking and reconstructing particular disciplines (education, theology, psychology, sociology, philosophy) from the perspective of the poor, the excluded, marginalised, or oppressed ${ }^{4}$, and through engagement and solidarity with

\footnotetext{
${ }^{4}$ These terms share a meaning but also have rather different resonances which will
} not be explored here, except to note that more recent writers have tended to prefer victims/victimisation and the excluded/exclusion rather than use the broader categories of the poor or the oppressed. 
them. The emphasis has been on the popular (populous) majorities of Latin America and the 'two-thirds world'.

\section{Core Ideas}

It is somewhat difficult to characterise all the psychological work from Latin America that has a liberatory orientation. Not all those working broadly within this tradition would want to use the title - indeed it is unlikely that anyone would claim to be a 'liberation psychologist', such a title sounding both pompous and pre-judgmental of the consequences of one's work. A further problem is that much of the work in the area is unpublished, especially where there is not a strong university base for the work. Accordingly, in published work there is something of a bias towards the more theoretical contributions and a lack of documentation of much innovative practice in the field. It is also not easy to obtain literature published in Latin America: for example much appears in small circulation books rather than in journals. Nevertheless several common themes permeate the work, both of those who have organised under this banner (for example at the annual international congresses of pscicología social de la liberación, since 1998), and those whose work would fit the paradigm even if they do not necessarily identify with it.

The term 'pscicología de la liberación' appears to have first appeared in print as early as 1976 (Caparrós \& Caparrós, 1976) in a text that in a similar way to the work of Lucien Sève $(1975 ; 1978)$ who undertook the task of elaborating the theoretical foundations of a psychology not founded on the philosophy of individualism. However, the term was brought into widespread 
use, with the meanings explored here, by two key writers, Ignacio Martín-Baró and Maritza Montero.

Ignacio Martín-Baró was a Jesuit priest and a senior academic at the University of Central America in San Salvador. He is the key thinker in LSP. He first used the term Psicología de la Liberación in 1986, but his writings and practice before and after this date form a body of 'Social Psychology from the Latin American reality' with an explicitly liberatory focus (Martín-Baró, 1986,

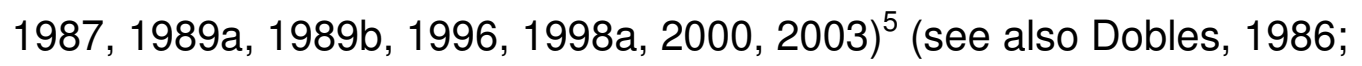
Pacheco \& Jiménez, 1990; Vázquez, 2000a). Martín Baró was one of the six Jesuits murdered in 1989 by an elite brigade of the Salvadorian army financed and trained by the USA (Galeano, 1998; Toomey, 2001), largely because of their even handed exposure of the reality of Salvadorian society in the context of the revolutionary uprising and civil war (de la Corte Ibañez, 2001; Sobrino, 1990).

Maritza Montero is a Venezuelan social and political psychologist. She has used the term since 1991 in a way similar to Martín-Baró, with an emphasis on overcoming dependency at both the individual and the community level. She had worked with an explicitly liberatory perspective from much earlier, chiefly in political psychology (Montero, 1991) and could

\footnotetext{
${ }^{5}$ Some of Martín-Baró's work has been collected in four posthumous collections,
} hence the post 1989 dates: Aron \& Corne's collection (Martín-Baró, 1996) in English, and the Spanish language collections edited by Blanco (Martín-Baró, 1998a), Blanco and de la Corte (Martín-Baró, 2003) and by Pacheco \& Jiménez (Pacheco \& Jiménez, 1990). Some of his books, including the two volumes of Psicología Social Desde Centroamérica are available by post from UCA Editores in El Salvador (http://www.uca.edu.sv/publica/ued/ucaeditores.html). 
now be regarded as the leading theorist in the field (Montero, 1997, 1998b, 2000a, 2000b, 2002).

In an English language text, Hollander (1997) used the term Liberation Psychology (with acknowledgement to Martín-Baró) to characterise the largely psychoanalytically informed work with the victims of the military dictatorships of the Southern Cone countries. However, this is a more restricted use of the term than that current in Latin America. In 2003 a special edition of the American Journal of Community Psychology, on the Psychology of Liberation, appeared, focussing chiefly on work outside Latin America that has a liberatory intent (Watts \& Serrano-García, 2003).

\section{Latin American Liberatory Praxis}

Over the last three decades or so a set of contributions has emerged in Latin America that could collectively be called Latin AmericanLiberatory Praxis, having both theoretical and practical elements, intimately connected. The main strands have been Critical Pedagogy (Freire, 1972; Kane, 2001), Economic Dependency Theory (Cardoso \& Faletto, 1979), Liberation Theology (Batstone, Mendieta, Lorentzen, \& Hopkins, 1997; Gutiérrez, 1973), the Sociology of Liberation and Participatory Action research (Fals Borda, 1988; Fals Borda \& Rahman, 1991), the Philosophy of Liberation (Alcoff \& Mendieta, 2000; Dussel, 1997, 1998) and the Psychology of Liberation itself.

A key theme in liberation thought is that liberation is not a thing that can be located in a moment in time. It is not something to be given, but rather it is a movement and a series of processes. It has its origins in the interaction of two types of agents or activists: - 
1. External catalytic agents (which could, for example, include community psychologists), and

2. The oppressed groups themselves.

This Latin American notion of liberation proposes a strategic alliance between these two sectors. A central idea is Freire's concept of conscientization $^{6}$ or the acquiring of a critical consciousness (Freire, 1972) explained by Martín-Baró (1986) as follows. The human being is transformed through changing his or her reality, by means of an active process of dialogue in which there is a gradual decoding of the world, as people grasp the mechanisms of oppression and dehumanisation. This opens up new possibilities for action. The new knowledge of the surrounding reality leads to new self-understanding about the roots of what people are at present and what they can become in the future. Freire was careful not to provide blueprints for this process, since every situation is different, and the danger is that the worker will misapply a concrete model from one context to another where the particularities are different.

Dussel (1998), in a panoramic work frequently cited by those working under the LSP banner, has summarised this and related models and experiences in more generalised terms. He posits a 'call' (interpellation) from

\footnotetext{
${ }^{6}$ Freire used the Portuguese term 'conscientização'. This translates into Spanish as 'conscientización', but there is not a straightforward English translation. 'Consciousness raising' is a possibility, but sounds more like a process of increasing awareness which could be via just that kind of passive unidirectional process which Freire criticises in conventional educational models. In fact Freire stopped using the term in 1974 because of just this lack of precision with which it was becoming used (Mayo, 1999; Torres, 1993).
} 
the self-aware (conscientised) victims (oppressed within a system or excluded from it) to those with an ethical conscience within the system. These two groups work together, identifying or denouncing what is wrong and constructing an alternative social reality - that is, on a shared project of liberation. As Martín-Baró and Montero have both stressed, ultimately this implies the liberation of the oppressors too.

\section{Realismo Crítico}

Martín-Baró established a distinctive position on the role of theory, one that is broadly followed by those working within this paradigm.

It shouldn't be theories that define the problems of our situation, but rather the problems that demand, and so to speak, select, their own theorisation.

(Martín-Baró, 1998b: p.314)

Theory therefore has a supportive but not a fundamental role, as a kind of scaffolding to guide action. This orientation he called 'realismo-crítico' ${ }^{17}$ in contrast to the more usual approach which he called 'idealismo-metodológico' (methodological idealism).

However, realismo-crítico is not a naïve realism: the nature of the social reality can be difficult to apprehend, not just for the people, but for the theory and practice of psychology itself. It is therefore necessary to deideologise reality, to peel off the layers of ideology (for Martín-Baró the

7 The obvious translation to 'critical realism' would risk confusion with the work of Roy Bhaskar on philosophy of science and social science (Bhaskar, 1997, 1998). Critical realism in this sense, although not inconsistent with Martín-Baró's concept, has a distinct meaning. 
disguised exercise of power) that individualise and naturalise phenomena such as the fatalism of Latin American societies (Martín-Baró, 1987).

The direction of travel sounds like that of Grounded Theory approaches to qualitative research (Strauss \& Corbin, 1990), where theory is meticulously built up from the ground of information collected by the researcher. The differences are firstly in a dialectical relationship between reality and theory for Martín-Baró there are certain meta-theoretical suppositions that precede the elaboration of theory, and ideally the theory interacts through action with the reality. Secondly, the theory has a role of de-ideologising reality - this is a critical thrust missing from phenomenological orientations such as Grounded Theory or Fourth Generation Evaluation (Guba \& Lincoln, 1989).

\section{A social orientation}

Throughout the work of those using LSP as an orienting vision, there is a thorough critique of the individualism found so strongly in North American (and indeed in British) psychology. Martín-Baró's two wonderful social psychology textbooks (Martín-Baró, 1983, 1989b) are perhaps the most sustained, thorough and engaged critique. This social or societal orientation is also historical, with a constant sense of how things got to be the way they are, and how this history is ever present in the subjectivity of the people. LSP practitioners have drawn on a variety of approaches here: Marxism, psychoanalysis, Vygotskian theory, social representations and social constructionism. But the social orientation is not just a matter of theory. LSP is a moral project (Montero, 2000b), and this tends to distinguish it from the new paradigm approaches of the 1970s and 1980s (Harré \& Secord, 1972; Reason \& Rowan, 1981), and much of the 'critical psychology' of the 1980s 
and 1990s (Ibañez \& Iñiguez, 1997; Potter \& Wetherall, 1987; see Parker, 1999, and Walkerdine, 2002 for overviews). The commitment after all is to liberation.

There are several aspects to this thoroughly social version of psychology. The recognition of the conflictual nature of society and the omnipresence of power is fundamental; there are distinct social interests that give rise to conflict. Power is to be understood not just on an interpersonal basis but in terms of its organisation in society. Conflict and power have both economic and ideological dimensions, the latter analysable using concepts from psychology.

Taken directly from liberation theology is the preferential option for the oppressed majorities. (Originally this was the 'preferential option for the poor', Gutiérrez, 1997). Psychology has to give up its obsession (idolatry) with its internal problems and focus on serving the needs of the popular majorities: it is their real problems, not those that preoccupy people elsewhere that should be the primary object of Latin American psychologists' attention. As the fulfilment of their needs depends on their liberation from the social structures that keep them oppressed, then that has to focus the concern and effort of psychology (Martín-Baró, 1986). The perspective and knowledge of the oppressed both provides content to psychology and sets a criterion for the 'practical truth' of psychology's offerings.

\section{Methodological eclecticism}

Those working with a LSP orientation combine traditional techniques (e.g. surveys, use of official statistics, content analyses) with new paradigm approaches (e.g. social representations, use of interviews and testimonies, 
collaborative photography, textual analysis, and drama), as well as 'ideology critique' that draws on both Foucauldian and related approaches. There is, however an emphasis on both the Freirean commitment to reflection-actionreflection (Freire, 1972), and to action research (Fals Borda, 1988; Fals Borda \& Rahman, 1991; see also Montero, 1998a, 2000a). Here is another contrast with much of the critical psychology practised in Europe, especially that which relies on textual criticism, in that LSP seems more open to the use of methods that stem from diverse paradigms. Perhaps the pressing social problems require a methodological pragmatism where the eclectic use of different methods is less problematic than in more theory driven contexts.

\section{Three areas of application}

LSP could be said to be applied in three main domains. These, however do overlap considerably, so, for example a piece of work recognisable as community psychology might also have a concern with state violence and impunity and with a broader socio-political analysis (Cordero, 1997; Dobles, 1994).

\section{Community Social Psychology}

Community psychology in Latin America has differed from that in the other America (Martín, 1998; Montero 1994, 1996, 1997, 1998a, 1998b; Quintal de Freitas, 2000; Riviera Medina \& Serrano Garcia, 1990; Sánchez , Weisenfeld, \& López Blanco, 1998; Sánchez \& Wiesenfeld, 1991; Tovar, 2001). Its roots are in social psychology, and there is less emphasis on the clinical and mental health tradition (one of the North American roots of the discipline). There has been an orientation to work with poor communities in 
settings as diverse as the poor urban districts of Caracas, San Juan or Sao Paulo, or rural squatter colonies in Costa Rica, or Mexico. Emphasis varies, but in general the psychologist is seen as a resource for the community, offering expertise in investigation, an understanding of leadership and organisation and group dynamics, and knowledge of the system (for example when trying to obtain resources). The themes of conscientisation (Freire, 1972) and the use of social science investigative methods (Fals Borda, 1988; Fals Borda \& Rahman, 1991) are typical, as is the effort to understand local struggle and self-liberation within a wider societal and global perspective.

Montero (1991: 35) suggests that community social psychology provides a methodological and empirical base for the psychology of liberation while participatory action research, dependency theory and popular education, together with the critical revision of traditional psychology, provide the theoretical support.

Community social psychology is taught at universities and / or practised in Venezuela, Mexico, Colombia, Puerto Rico, Cuba, Costa Rica, Brazil, Chile, Peru and Argentina. A variety of social issues is tackled, including for example health promotion, economic development and antipoverty programmes, housing, leadership development at the community level, community development, as well as the development of community intervention and support in the fields of disability, domestic violence, mental health and drug use.

In general a transformational approach is either employed or aspired to. In some cases the psychological specificity can risk being lost, although this matter has been addressed within the field. Quintal de Freitas (1994) for 
example, defines community social psychology as a position and practice that both defends the specificity of psychological practice, and the belief in sociohistorical determination of social phenomena. Setting out to demystify and de-ideologize difficulties faced by people (typically naturalised and psychologised), it employs both the use of psychological techniques already existing in psychology and also the creation of new ones in a joint process of participation with the people concerned. Presumably this professional specificity would only come into play once there has been a commitment to and analysis of the socio-historical nature of social problems. Otherwise there is the strong possibility of just 'doing traditional psychology in community settings'.

\section{Work with victims of state oppression (disappearances, genocide)}

Latin America has suffered oppressive regimes, military conflicts and the repression of liberation movements. There are still reports of murders of activists (e.g. in Mexico, Guatemala, Brazil, and especially in Colombia), the clearance of peasants from prime land (Colombia), and other abuses. The experience has been diverse in scale and intensity, but the psychosocial experiences in countries as different as the Southern Cone, the Andean countries and Central America have been in many ways similar. To give some idea of the scale of the trauma, there were some 20,000 murders by the Argentinian junta (Hollander, 1997), 3,000 in Chile (Reuters, 2003), and more than 200,000 by the Guatemalan state $(\mathrm{CEH}, 1999)$. There have been several threads to the work here with survivors and those close to the victims of torture, disappearance and murder. For Martín-Baró himself, living in the 'limit situation' of the El Salvador conflict (Harris, 1990) political violence was a 
key practical and theoretical concern (Dobles, 1993; Martín-Baró, 2003, 2000).

An outstanding example of this is found in the work of ILAS, the Instituto Latinoamericano de Salud Mental y Derechos Humanos (Latin American Institute of Mental Health and Human Rights), a non governmental organisation working on the mental health of people affected directly as a result of the violations of human rights during the military regime in Chile, 1973-1990 (ILAS, 2003). Extensive research was carried out to inform the work, covering violations of human rights, their effects on people in particular and also on society in general. ILAS is also active in the establishment and supervision of other mental health teams which work with people who have experienced situations of political violence, both nationally and internationally, for example in Angola (Agger \& Buus Jensen, 1996; ILAS, 2003). Meanwhile, in Chile the discussions about the social, subjective and political implications of seventeen years of authoritarian government still continue. The concern for social reparation to the victims is still important, with the question of national unity and reconstruction a theme in Chilean mental health, with a political and public dimension.

In the work of ILAS and other teams, for example the psychosocial support team for the Mothers of the Plaza de Mayo in Buenos Aires (Hollander, 1997) and in the AVRE organisation in Colombia (Castaño \& López, 1994), there is emphasis on making the suffering a social, shared, thing, rather than secret distress, and on again taking up active social roles. Agger and Buus Jensen (1996: 105) describe this as de-privatization. In the 
course of their work, the Buenos Aires group has produced evidence of the healing power of political activism (cited by Hollander, p. 143).

Among the nine objectives by which Lira and Weinstein (2000) defined the ILAS therapeutic model, the following four indicate the highly social and societal orientation, going beyond the more usual models of working with post traumatic disorder:

- Linking of the traumatic experience to existential meanings in the life of the person,

- Regaining of role as a social being,

- Restructuring of the (person's) existential project: continuity between past, present and future

- Regaining of collective ties.

Our therapeutic focus gives decisive importance to the existential restructuring of the existential project which has been found to be directly associated with recovery (recuperación) of an active social role.

Psychotherapy then, has to be accompanied by conditions that help the [person] to regain the former sense of their life, or that permit, in paradoxical contradiction to the intentions of the torturer, the personal growth and development of the person who was victim.

(Lira \& Weinstein, 2000p. 387)

Lira and Weinstein also emphasise the need of the therapist to be able to interpret experiences sociopolitically, in order that the affected person can in answering the questions 'why torture?' and 'why me?' discover the rationality in a situation so often characterised by arbitrariness and confusion.

The theme of recovering memories, of what happened, and of those who have been taken away is common to this and other work. This emphasis 
is important both in terms of the general emphasis in liberatory praxis on the role of collective memory as a political and social resource, but also because of the officially sanctioned denial of what happened. In Guatemala, the disinterring of the murdered, identifying them, and commemorating what happened, for example through traditional Maya ceremonies, is of key importance, with several interdisciplinary projects under way.

A further dimension to all this has been work to prosecute and end the impunity of those responsible, with psychologists working as a resource to lawyers, forensic archaeologists, and others as well as community members (Flores et al., 2002; Lira, 2000; Reza, undated). The international LSP congresses have been important places to exchange experiences (for example between those working in El Salvador and Guatemala).

The therapeutic approach meets a community psychological one in work on delivering effective intervention to communities without access to mental health professionals (Sveaass, 2000).

\section{Social Analysis}

Given the emphasis on a macro-social viewpoint, intimately linked to human subjectivity, it is no surprise that psychologists working within the LSP approach have explored social analysis more broadly.

A large part of Martín-Baró's work was on Salvadorean public opinion (Martín-Baró, 1989a). Although this used conventional survey methods it had a clear purpose of making explicit what the people thought, providing the information to people and organisations in both inside and outside the country. As such the work was a form of counter-propaganda, undermining many of the arguments used to justify continued support for the government. 
It was also an independent source of information for peace activists outside the country, especially in the USA. The University Institute of Public Opinion, IUDOP, which he established, still functions and continues this work 'so that the citizens see themselves as themselves, and generate the changes that are still necessary in a society divided by poverty and violence' (IUDOP, 2003).

Other psychologists working with a LSP perspective have carried out various socio-psychological-political analyses of the social realities confronting their countries. At the 2002 International Congress of LSP in Guadalajara, Mexico, for example, there were analyses of the use of terror by the Colombian paramilitaries and its effects on family life and subjectivity, the use of psychological warfare in the Guatemalan counter-insurgency and genocide, and the Bush regime's use of propaganda after the twin towers attack.

Other work has focussed on matters such as child development under conditions of institutionalised violence, the process of urbanisation, rural issues, and the new social movements in the region (Cordero, 1997; Gaborit, undated; Vázquez, 2000b).

There has been a variety of new developments in the region, such as the erosion of impunity, the emergence of new social movements and actors, the election of more progressive governments or at least of increasing numbers of progressive parliamentarians, together with the intensification of Washington's economic and military interference. These appear to be leading to an increasing interest in political and social commentary, and to the search for new means of intervening in the public sphere (Dobles, 2003). 
So, there is no one unified approach that could be called 'Liberation Social Psychology', but there is a family of approaches that fit the title and show sufficient use and development of the fundamental ideas to allow the application of the term.

\section{Challenges}

Despite its broader relevance to work with marginalised populations, and the stature of its leading practitioners, Liberation Social Psychology is little known outside Latin America, and even there it is very much a minority tendency. It has a tendency to continually restate its distinc tive approach, perhaps at the expense of further development. At the same time there is what Montero (personal communication, 2002) has identified as a continual risk of a drift to mere activism, or the use of liberatory language to cover uncritical repeated practices where abuse and exploitation return. Finally, like any progressive social movement, it truly faces an enormous task in nourishing both opposition to the empire of capitalist exploitation and domination, and developing viable support systems, both for itself as well as with and for the marginalised and oppressed.

LSP, then, is a minority interest with credence only in certain locations. The annual conferences attract several hundred people, many of them local: the travel costs are prohibitive for most people. There is little continuity of the network between events, although the fifth 2002 congress did focus to some extent on this problem. There is a small network of enthusiasts some of whom do have a respected status in the discipline.

The quality of debate is high, although there is not a great deal of original new work being done. The North American critical psychologist Tod 
Sloan (personal communication, 2002) makes the comparison with critical psychology:

In general, Latin American academics have few resources and little time for keeping up with theory in the way British progressives seem to do. In the UK, there often seems to be too much theory and in Latin America too little.

While, politically speaking, there are some promising openings in the region, there are enormous forces working against initiatives such as these. The continued economic problems of the region and the continued dominance and interference by the USA make for a real limit on the scope for the liberation of those excluded from capitalism's party.

The interests of academics and professionals are not always the same as those of the oppressed sectors, and the linkage between progressive social psychologists and other progressive movements is not strong. The fourth, 2001 International Congress of LSP in Guatemala saw a noteworthy attempt to link with and involve popular social movements from Guatemala and beyond, providing a critical edge for debate and clarification. There was an impressive talk by Horacio Martins de Carvalho from the Brazilian Landless Workers Movement (MST) which covered the nature of the struggle for social justice, land occupations and the new democratic communities that have arisen, together with the cultural practices that have evolved to support the struggle. This effectively framed the conference within the problematic of what psychology can contribute, and what kind of psychological knowledge and practice is appropriate. But the objective differences between the 
professional middle class and the excluded is a real challenge to overcome one that is not unique to Latin America (Stewart, 2000).

Some initiatives are taking place to give more voice to LSP. Between the original writing of this article and its revision in April 2004 an email network (in Spanish) has been set up and a web resource is being prepared. While LSP is orientated chiefly to the specific problems of Latin America, in a globalised world many of the problems are no longer of local interest only, and just as the work of Freire, Fals-Borda, Boal (1979), Gutiérrez, and others from the first wave of Latin American liberatory praxis inspired intellectuals and activists in Europe, so it is important to encourage translation and dissemination of more recent work. Finally it is important that community, applied social, and critical psychologists engage with each other and with this other body of work, in that spirit of open, principled and dialogic encounter that runs through both LSP and the broader tradition of liberatory praxis.

5080 words 


\section{References}

\section{References Cited:}

Agger, I., \& Buus Jensen, S. (1996) Trauma and Healing under State Terrorism. London: Zed.

Alcoff, L., \& Mendieta, E. (Eds.) (2000) Thinking from the Underside of History: Enrique Dussel's Philosophy of Liberation. Lanham, Maryland: Rowman and Littlefield.

Armistead, N. (Ed.) (1974) Reconstructing Social Psychology. Harmondsworth: Penguin.

Aron, A., \& Corne, S. (Eds.) (1996) Ignacio Martín-Baró: Writings for a Liberation Psychology. New York: Harvard University Press.

Batstone, D., Mendieta, E., Lorentzen, L. A., \& Hopkins, D. N. (Eds.) (1997) Liberation, Theologies, Postmodernity, and the Americas. New York and London: Routledge.

Bhaskar, R. (1997) A Realist Theory of Science (Second ed.) London: Verso. Bhaskar, R. (1998) The Possibility of Naturalism: A Philosophical Critique of the Contemporary Human Sciences (Third ed.) London: Routledge.

Blanco, A. (1998) Introducción. In Psicología de la Liberación. Madrid: Trotta.

Boal, A. (1979) Theatre of the Oppressed. London: Pluto Press.

Burton, M. (2004) Radical psychology networks: a review and guide. Journal of Community \& Applied Social Psychology, 14, 119-130.

Burton, M. (in press) Viva Nacho! Liberating psychology in Latin America. The Psychologist. 
Burton, M., \& Kagan, C. (in press) Marginalization. In G. Nelson \& I.

Prilleltensky (Eds.), Community Psychology: In pursuit of wellness and liberation. London: MacMillan/Palgrave.

Caparrós, A., \& Caparrós, N. (1976) Psicología de la Liberación. Madrid: Editorial Fundamentos.

Cardoso, F., \& Faletto, E. (1979) Dependency and Development in Latin America. Berkeley, California: University of California Press.

Castaño, B. L., \& López, P. (1994) Chapter 2. In E. Lira (Ed.), Psicología y Violencia política en América Latina. (pp. 37-69) Santiago de Chile: ILAS / Ediciones CESOC.

CEH. (1999) Guatemala: Memory of Silence. Conclusions and recommendations of the report of the commission for historical clarification. Guatemala: Guatemalan Commission for Historical Clarification (CEH) and American Association for the Advancement of Science, Science and Human Rights Program (also available at http://shr.aaas.org/guatemala/ceh/ in English and Spanish).

Cordero, T. (1997) Organización, identidad y violencia en la lucha por la tierra en Pavones del Golfito, un vistazo de la experiencia. In M. Montero (Ed.), Psychology and Community / Psicología y Communidad. Caracas: Sociedad Interamericana de Psicología. de la Corte lbañez, L. (2001) Memoria de un Compromiso: La psicología de Ignacio Martín-Baró. Bilbao: Desclée de Brouwer. de la Corte lbañez, L. (undated) La psicología de Ignacio Martín-Baró como psicología crítica: una presentación de su obra. Retrieved 13/12/2001, from http://www.cop.es/delegaci/madrid/pspolitica/baro.htm 
de la Torre, C. (1997) Psicología latinoaméricana: entre la dependencia y la identidad. Havana: Editorial 'Felix Varela'.

Dobles, I. (1986) Psicología social desde centroamerica: retos y perspectivas. Entrevista con el Dr. Ignacio Martin-Baró. Revista Costarricense de Psicología (8-9), 71-76.

Dobles, I. (1993) El concepto de violencia en el pensamiento de Ignacio Martín Baró. Comportamiento, 2(2), 87-95.

Dobles, I. (1994) Psicología de la liberación: dificultades de una busqueda. Reflexiones, 30, 27-37.

Dobles, I. (2003) La invasión de Irak y la manipulación de masas. Unpublished talk to journalists.

Dussel, E. (1997) The architectonic of the ethics of liberation. In D. Batstone, E. Mendieta, L. A. Lorentzen \& D. N. Hopkins (Eds.), Liberation Theologies, Postmodernity, and the Americas. New York and London: Routledge.

Dussel, E. (1998) Ética de la Liberación en la Edad de la Globalización y de la Exclusión. Madrid: Trotta.

Fals Borda, O. (1988) Knowledge and People's Power: Lessons with Peasants in Nicaragua, Mexico and Colombia. New York: New Horizons Press.

Fals Borda, O., \& Rahman, M. A. (1991) Action and Knowledge: Breaking the monopoly of power with participatory action-research. London: Intermediate Technology Publications.

Flores, J. M., Cajas, E., Navarra, S., Salado, M., Suasnavar, J., \& Solis, R. (2002) Symposium: El papel de la psicología en el proceso de 
exhumaciones en guatemala. Paper presented at the Fifth Congreso Internacional de la Psicología Social de la Liberación, Guadalajara, Mexico.

Freire, P. (1972) Pedagogy of the Oppressed. Harmondsworth: Penguin. (also NY: Continuum, 1993)

Gaborit, M. (undated) Psicología social de la niñez en El Salvador: condicionantes en la construcción de la preciudadanía. Retrieved 16/02/2002, from http://www.uca.edu.sv/publica/eca/595art4.html

Galeano, E. (1998) Patas Arriba: La Escuela del Mundo al Revés. Madrid: Siglo XXI.

Guba, E. G., \& Lincoln, Y. S. (1989) Fourth Generation Evaluation. Newbury Park, California: Sage.

Gutiérrez, G. (1973) A Theology of Liberation (M. O'Connell, Trans.) Maryknoll, New York: Orbis.

Gutiérrez, G. (1997) Renewing the option for the poor. In D. Batstone, E. Mendieta, L. A. Lorentzen \& D. N. Hopkins (Eds.), Liberation Theologies, Postmodernity and the Americas. London: Routledge.

Harré, R., \& Secord, P. F. (1972) The Explanation of Social Behaviour. Oxford: Blackwell.

Harris, A. (1990) A Psychologist in El Salvador. The Psychologist, 264-266. Hollander, N. C. (1997) Love in a time of hate: Liberation psychology in Latin America. New Brunswick, New Jersey: Rutgers University Press.

Ibañez, T., \& Iñiguez, L. (Eds.) (1997) Critical Social Psychology. London: Sage.

ILAS. (2003) Retrieved 15/6/2003, from http://www.ilas.cl/presenta.htm 
IUDOP. (2003) Instituto Universitario de Opinión Pública. Retrieved 9/9/2003, from http://www.uca.edu.sv/publica/iudop/principal.htm Jara, V. (1970) Caminando, Caminando [Recorded by V. Jara]. On Victor Jara, complete [Compact Disc]. Dortmund: Verlag Pläne.

Jiménez , B. (1990) Psic-Pol: Notas críticas sobre la psicología dominante. In B. Jiménez (Ed.), Aportes Críticos a la Psicología en Latinoamerica (pp. 112-138) Guadalajara, Mexico: Universidad de Guadalajara.

Kane, L. (2001) Popular Education and Social Change in Latin America. London: Latin America Bureau.

Lira, E. (2000) Verdad, justicia e impunidad. Memoria, perdón y olvido. In J. J. Vázquez (Ed.), Psicología social y liberación en América Latina (pp. 133-153) Mexico City: Universidad Autónoma Metropolitana, Iztapalapa.

Lira, E., \& Weinstein, E. (2000) La tortura. Conceptualización psicológica y proceso terapéutico. In I. Martín-Baró (Ed.), Psicología social de la guerra (Third ed.) San Salvador: UCA Editores.

Lykes, M. B. (2000) Possible contributions of a psychology of liberation: Whither Human Rights? Journal of Health Psychology, 5, 383-397. Martín, A. (Ed.) (1998) Psicología Comunitaria: fundamentos y aplicaciones. Madrid: Editorial Síntesis.

Martín-Baró, I. (1983) Acción e Ideología: Psicología social desde Centroamérica I. San Salvador: UCA Editores.

Martín-Baró, I. (1987) El latino indolente. Carácter ideológico del fatalismo latinoamericano. In M. Montero (Ed.), Psicología Política Latinoamericana. (pp. 135-162) Caracas: Panapo. Translated as The 
Lazy Latino: The ideological nature of Latin American fatalism. Chapter 12 of Martín-Baró (1996).

Martín-Baró, I. (1989a) La opinión pública salvadoreña (1987-1988) San Salvador: UCA Editores.

Martín-Baró, I. (1989b) Sistema, Grupo y Poder: Psicología social desde Centroamérica II. San Salvador: UCA Editores.

Martín-Baró, I. (1986) Hacia una psicología de la liberación. Boletin de Psicología (UCA) 22, 219-231 (available in Internet: http://www.uca.edu.sv/deptos/psicolog/hacia.htm accessed 23/2/2002). Translated as Toward a liberation psychology. in MartínBaró (1996).

Martín-Baró, I. (1996) Writings for a Liberation Psychology. New York: Harvard University Press.

Martín-Baró, I. (1998a) Psicología de la Liberación. Madrid: Trotta.

Martín-Baró, I. (1998b) Retos y perspectivas de la psicología latinoamericana. In A. Blanco (Ed.), Psicología de la Liberación (pp. Reprinted as part 2 of Chapter 10) Madrid: Trotta.

Martín-Baró, I. (Ed.) (2000) Psicología social de la guerra: trauma y terapia (3 ed.) San Salvador: UCA Editores.

Martín-Baró, I. (2003) Poder, ideología y violencia. Madrid: Trotta.

Mayo, P. (1999) Gramsci, Freire and Adult Education: Possibilities for Transformative Action. London: Zed Books.

Montero, M. (1991) Psicología de la liberación. Propuesta para una teoría psicosociológica. In H. Riquelme (Ed.), Otras realidades, otras vías de acceso (pp. 133-150.) Caracas: Nueva sociedad. 
Montero, M. (Ed.) (1994) Psicología Social Comunitaria. Guadalajara, Mexico: Universidad de Guadalajara.

Montero, M. (1996) Parallel lives: community psychology in Latin America and the United States. American Journal of Community Psychology, 24, 589-606.

Montero, M. (Ed.) (1997) Psicología y Comunidad: Memorias de Psicología Comunitaria, XXV Congreso Interamericano de Psicología, 1995. San Juan, Puerto Rico: Sociedad Interamericana de Psicología with Universidad Central de Venezuela.

Montero, M. (1998a) La comunidad como objetivo y sujeto de la acción social. In A. Martín (Ed.), Psicología Comunitaria: Fundamentos y Aplicaciones (pp. 211-222) Madrid: Editorial Síntesis.

Montero, M. (1998b) Psychosocial community work as an alternative mode of political action (the construction and critical transformation of society). Community Work and Family, 1(1), 65-78.

Montero, M. (2000a) Participation in participatory action research. Annual Review of Critical Psychology, 2, 131-144.

Montero, M. (2000b) Perspectivas y retos de la psicología de la liberación. In J. J. Vazquez (Ed.), Psicología Social y Liberación en América Latina (pp. 9-26) Mexico City: Universidad Autonoma de Mexico, Unidad de Iztapalapa.

Montero, M. (2002) On the construction of reality and truth. Towards an epistemology of community social psychology. American Journal of Community Psychology, 30(4), 571-584. 
Pacheco, G., \& Jiménez, B. (Eds.) (1990) Ignacio Martín-Baró (1942-1989):

Psicología de la Liberación para America Latina. Guadalajara: Universidad de Guadalajara.

Parker, I. (1989) The Crisis in Modern Social Psychology - and how to end it. London: Routledge.

Parker, I. (1999) Critical psychology: critical links. Annual Review of Critical Psychology, 1, 3-18.

Potter, J., \& Wetherall, M. (1987) Discourse and Social Psychology: Beyond Attitudes and Behaviour. London: Sage.

Quintal de Freitas, M. d. F. (1994) Prácticas en comunidad y psicología comunitaria. In M. Montero (Ed.), Psicología Social Comunitaria: Teoría, método y experiencia. Guadalajara: Universidad de Guadalajara.

Quintal de Freitas, M. d. F. (2000) Voices from the South: the construction of Brazilian community social psychology. Journal of Community \& Applied Social Psychology, 10 (4) 315 - 326.

Reason, P. \& Rowan, J. (Eds.) (1981) Human Inquiry: A Sourcebook of New Paradigm Research. Chichester: Wiley.

Reuters. (2003, November 26, 2003) The Guardian, p. 18.

Reza, J. L. (undated) Voces de la Tierra: La guerra sucia en Guatemala [Videotape]. Mexico City.

Riviera Medina, E., \& Serrano Garcia, I. (1990) El desarrollo de la psicología de communidad en latinoamérica. In B. J. Dominguez (Ed.), Aportes Criticos a la Psicología en Latinoamerica. (pp. 222-245) Guadalajara:: Editorial Universidad de Guadalajara. 
Sánchez , E., Weisenfeld, E., \& López Blanco, R. (1998) Trayectoria y perspectivas de la psicología social comunitaria en América Latina. In A. Martín (Ed.), Psicología Comunitaria: fundamentos y aplicaciones (pp. 159-172) Madrid: Editorial Síntesis.

Sánchez, E., \& Wiesenfeld, E. (1991) Special Issue: Community Social Psychology in Latin America. Applied Psychology: An International Review, 40 (2), 111-236.

Sève, L. (1975) Marxism and the Theory of Human Personality. London: Lawrence and Wishart.

Sève, L. (1978) Man in Marxist Theory and the Psychology of Personality. Sussex: Harvester Press.

Sobrino, J. (1990) Companions of Jesus: The Murder and Martyrdom of the Salvadorean Jesuits. London: Catholic Institute for International Relations.

Stewart, A. (2000) Unpaid work in the community: an account of becoming a community activist. Community, Work and Family, 3(1), 111-114.

Strauss, A., \& Corbin, J. (1990) Basics of Qualitative Research: Grounded Theory Procedures and Techniques. Newbury Park, California: Sage.

Sveaass, N. (2000) Psychological work in a post-war context: experiences from Nicaragua. Community Work and Family, 3(1), 37-64.

Toomey, C. (2001) Escuela de dictadores. El País Semanal, (1,316), p. 72, 16/12/2001.

Torres, C. A. (1993) From the Pedagogy of the Oppressed to A Luta Continua: The Political Pedagogy of Paulo Freire. In P. McLaren \& P. 
Leonard (Eds.), Paulo Freire: A Critical Encounter (pp. 119-145) London: Routledge.

Tovar, M. (2001) Psicología Social Comunitaria: Una Alternativa TeoricoMetodológica. Mexico City: Plaza y Valdes.

Vázquez, J. J. (2000a) Compromiso social y político en la psicología social de la liberación,de Ignacio Martín Baró (1942-1989) Polis, Revista del Departamento de Sociología, Universidad Autónoma Metropolitana, Unidad Iztapalapa., 1, 263-289.

Vázquez, J. J. (2000b) La importancia de la psicología social de la liberación para el análisis de los nuevos movimientos sociales. In J. J. Vazquez (Ed.), Psicología Social y Liberación en América Latina (pp. 41-52) Mexico City: Universidad Autonoma de Mexico, Unidad de Iztapalapa.

Walkerdine, V. (2002) Editorial: Traditions of critical psychology. Critical Psychology, 2, 1-3.

Watts, R. J., \& Serrano-García, I. (2003) Special section: The Psychology of Liberation: Responses to Oppression. American Journal of Community Psychology (Vol. 31 (1/2), pp. 73-203)

\section{Further useful texts in English}

Comás Diaz, L, Lykes, M.B., and Alarcon, R. D. (1998) Ethnic conflict and the psychology of liberation in Guatemala, Peru, and Puerto Rico. American Psychologist, $\underline{53}, 778-792$.

Dussel, E.D. and Mendieta, E (2003) Beyond Philosophy: Ethics, History, Marxism, and Liberation Theology (New Critical Theory) Rowman \& Littlefield. 
Freire, P. (1994) Pedagogy of Hope NY: Continuum.

Hall, J. M. (1999) Marginalization revisited: critical, postmodern, and liberation perspectives. Advances in Nursing Science, 22(2), 88-102.

Hanna, F. J., Talley, W. B., \& Guindon, M. H. (2000) The power of perception: toward a model of cultural oppression and liberation. Journal of Counseling and Development, 78(4), 430-441.

Kelman, H.C. (1995) Ignacio Martín-Baró: a personal remembrance of a peace psychologist. Journal of Peace Psychology, 1, (1), 11-15.

Lykes, M.B. (2000) Possible contributions of a psychology of liberation: Whither Human Rights? Journal of Health Psychology $\underline{5}$, 383397.

Lykes, M.B. (2001) Creative arts and photography in participatory action research in Guatemala. In J. Reason (Ed.) Handbook of Action Research. (pp. 363-371), London, Sage.

Perilla, J. L. (1999) Domestic violence as a human rights issue: the case of immigrant Latinos. Hispanic Journal of Behavioral Sciences, 21(2), 107-133. 